\title{
Effects of coriander (Coriandrum sativum L.) seed powder and extract on performance of broiler chickens
}

\author{
M. Naeemasa ${ }^{1}$, A. A. Alaw Qotbi ${ }^{1}$, A. Seidavi ${ }^{1 \#}$, D. Norris ${ }^{2 \#}$, D. Brown ${ }^{2 \#} \&$ M. Ginindza ${ }^{2}$ \\ ${ }^{1}$ Department of Animal Science, Rasht Branch, Islamic Azad University, Rasht, Iran \\ ${ }^{2}$ Department of Agricultural Economics and Animal Production, University of Limpopo, Private Bag X1106, \\ Sovenga, 0727, South Africa
}

(Received 7 May 2014; Accepted 9 March 2015; First published online 3 September 2015)

\author{
Copyright resides with the authors in terms of the Creative Commons Attribution 2.5 South African Licence. \\ See: http://creativecommons.org/licenses/by/2.5/za \\ Condition of use: The user may copy, distribute, transmit and adapt the work, but must recognise the authors and the South African \\ Journal of Animal Science.
}

\begin{abstract}
This study was conducted to investigate the effects of different levels of coriander (Coriandrum sativum) seed powder and extract on the performance and carcass characteristics of broiler chickens. A total of 420 day-old broiler chicks (Ross 308) were allocated randomly into seven treatments of 60 birds per group. Each treatment had four replicates (15 chicks per replicate). The trial was designed with seven treatments, consisting of a control diet without coriander, this is, the control group (CG); three treatments, which included the control diet plus three levels of coriander extract in water $(750,1000$, and $1250 \mathrm{mg} / \mathrm{kg}$ ); and the another three, which received the control diet plus three levels of coriander powder $(1.5 \%, 2.0 \%$ and 2.5\%). Performance parameters were monitored throughout the experimental period. At $21-42 \mathrm{~d}$ old, the inclusion of $952 \mathrm{mg} / \mathrm{kg}$ of coriander extract in drinking water maximized weight gain, while the feed intake of the experimental period ( $1-42 \mathrm{~d}$ ) was maximized at the coriander powder level of $1.2 \%$. Feed conversion ratios improved with the inclusion of coriander powder in the diet throughout the experimental period. These results suggest that coriander powder in the diet and coriander extract in water could replace synthetic antibiotics and could be regarded as natural feed additives and growth promoters in poultry diets.
\end{abstract}

Keywords: Additives, broiler, herbs, spices

\# Corresponding authors: David.Norris@ul.ac.za; David Brown- db4010396@gmail.com; alirezaseidavi@yahoo.com

\section{Introduction}

In recent times, consumers of poultry products have become more concerned about synthetic additives in animal feed, which have reportedly shown DNA damage induction in the gastrointestinal organs of mice at low doses (Sasaki et al., 2002) and may pose a serious threat to human health. The use of herbs and spices is a promising alternative to these synthetic additives. Herbs and spices possess anti-oxidant activities (Madsen \& Bertelsen, 1995) and are known for their potential antimicrobial and stimulating effects on the digestive system (Windisch et al., 2008). Lippens et al. (2005) reported that broiler chicks supplemented with plant extract had better feed conversion ratios (FCRs) and reached higher bodyweights than the control and avilamycin groups. In general, the use of herbs, spices and their extracts improved the flavour and palatability of feed, thus enhancing production performance.

Coriander (Coriandrum sativum L.) is regarded as both a herb and a spice, and reputedly has health advantages. It has been used in medicine for thousands of years (Nadeem et al., 2013). Certain parts of this plant, such as the leaves, flowers, seeds and fruit, possess antioxidant, diuretic, anti-diabetic, sedative, antimicrobial, anthelmintic and anti-mutagenic qualities (Pathak et al., 2011; Rajeshwari \& Andallu, 2011).

However, reports about the effects of herbal extracts and seeds on broilers are inconsistent. Some authors found that many herbs and spices had positive effects on animal nutrition (Wenk, 2006; Al-jaff, 2011), whereas others did not find clear evidence (Windisch et al., 2008). Thus, the objective of this study was to investigate the effects of various levels of coriander seed powder and extract as diet ingredients on the performance and carcass characteristics of broiler chickens.

\section{Materials and Methods}

A feeding trial was conducted at the poultry farm of the Animal Science Department, Rasht Branch, Islamic Azad University. The study was carried out in an environmentally controlled poultry house. Birds 
were housed in pens. Floor pens were assigned to the seven treatments. The distribution of experimental pens was arranged to avoid effects from location in the poultry house. A total of 420 day-old broiler chicks (Ross 308) were allocated randomly into seven treatments of 60 birds per group. Each treatment had four replicates (15 chicks per replicate). The trial was designed with seven treatments, consisting of a control diet without coriander as the control group (CG); three treatments which included the control diet plus three levels of coriander extract in water $(750,1000$ and $1250 \mathrm{mg} / \mathrm{kg}$ ); and three treatments which received the control diet plus three levels of coriander powder $(1.5 \%, 2.0 \%$ and $2.5 \%)$. The experiment involved two feeding periods, namely starter ( $1-21 \mathrm{~d}$ old $)$ and finisher (22 - $42 \mathrm{~d}$ old). The experimental diets were formulated according to National Research Council (NRC) regulations (1994). The ingredients and chemical composition of the experimental basal diets are presented in Table 1.

The birds had free access to feed and water. Each pen was equipped with a feeder and drinker. New wood shavings were used as litter. The initial brooding temperature was held at $32^{\circ} \mathrm{C}$ for the first three days, then gradually lowered to $23{ }^{\circ} \mathrm{C}$ by the end of the experiment. Photoperiods were maintained at $24 \mathrm{~h} / \mathrm{d}$ for the first week and decreased to $23 \mathrm{~h} / \mathrm{d}$ for the rest of the trial.

Table 1 Dietary ingredients and chemical composition of the basal diets during the starter ( 1 - 21 days) and grower (22 - 42 days) periods

\begin{tabular}{|c|c|c|}
\hline Ingredient (g/kg) & Starter & Grower \\
\hline Wheat bran ${ }^{1}$ & 25.0 & 25.0 \\
\hline Maize & 505 & 551 \\
\hline Soybean meal & 394 & 317 \\
\hline Soybean oil & 31.8 & 66.0 \\
\hline Ca\%22,P\%18 & 21.1 & 17.3 \\
\hline $\mathrm{CaCO}_{3}$ & 9.6 & 8.6 \\
\hline $\mathrm{NaCl}$ & 2.7 & 2.8 \\
\hline DL-Methionine & 2.4 & 2.6 \\
\hline L- Lysine-hydro-chloride & 0.8 & 0.6 \\
\hline Threonine & 0.7 & 0.9 \\
\hline Sodium bicarbonate $\left(\mathrm{NaHCO}_{3}\right)$ & 2.8 & 2.7 \\
\hline Vitamin and mineral premix* & 5.0 & 5.0 \\
\hline \multicolumn{3}{|l|}{ Analysed nutrients } \\
\hline Energy (ME) (MJ/kg) & 12.6 & 12.6 \\
\hline Crude protein & 205 & 194 \\
\hline Calcium & 10.0 & 8.50 \\
\hline Available phosphorus & 5.00 & 4.20 \\
\hline DCAB (mEq/kg) & 236 & 202 \\
\hline Lysine $\left(\mathrm{SID}^{* *}\right)$ & 11.5 & 9.60 \\
\hline Methionine $\left(\mathrm{SID}^{\star *}\right)$ & 5.00 & 4.80 \\
\hline Methionine+cysteine (SID**) & 8.30 & 7.80 \\
\hline Threonine $\left(\mathrm{SID}^{* *}\right)$ & 7.9 & 7.10 \\
\hline
\end{tabular}

The birds were vaccinated against Infectious bronchitis (1st and 7th day), Newcastle Disease (1st and 7th day), Avian Influenza (1st day) and Infectious bursal disease (21st day). 
Coriander seeds were purchased from the local market, and were ground separately to a fine powder. In preparing the coriander extract for the experiment, dried coriander seeds were ground to a fine powder, of which $100 \mathrm{~g}$ was added to $500 \mathrm{~mL}$ distilled water. After $24 \mathrm{~h}$ maceration at room temperature $\left(37^{\circ} \mathrm{C}\right)$, the mixture was heated for 30 minutes in a water bath set to $65^{\circ} \mathrm{C}$. The extract was filtered, concentrated by heating over the water bath $\left(65^{\circ} \mathrm{C}\right)$, and dried under vacuum (Gray \& Flatt, 1999) with a yield of 5.9\% (w/w). The extract was stored at $4{ }^{\circ} \mathrm{C}$ and used in the experiment as needed. Proximate analysis of coriander powder (Table 2) was determined according to the methods of AOAC (1990).

The live weights of the birds were measured at the beginning of the experiment, then at weekly intervals. Feed intake, growth rate and FCR were determined according to the procedures of McDonald et al. (2011). At 42 d, four birds per replicate were randomly chosen, weighed and slaughtered by cervical dislocation, as recommended by Islamic Azad University Committee on Animal Ethics. The feathers were removed and internal organs were collected. Weights of fresh heart, liver, gall bladder and gizzard were measured relative to live bodyweight ( $\mathrm{g} / \mathrm{kg}$ ), as indicated by Jiménez-Moreno et al. (2011).

The dose-related responses to coriander extract in water and coriander powder in diet were modelled according to this quadratic equation:

$$
Y=a+b_{1} x+b_{2} x^{2}
$$

where $Y=$ live weight, feed intake, growth rate, FCR, carcass characteristics; $a=$ intercept; $b_{1}$ and $b_{2}=$ coefficients of the quadratic equation; $x=$ coriander extract in water and powder in diet; and $-b / 2 b_{2}=x$ value for optimal response. The quadratic model was fitted to the experimental data by using the nonlinear regression model (NLIN) procedure of SAS (2008). Linear regressions were modelled using the following equation:

$$
Y=a+b x
$$

where $Y=$ live weight, feed intake, growth rate, FCR, carcass characteristics; a = intercept; and $b=$ coefficient of the linear equation.

Before performing the statistical analysis, all data were tested with a normality test. Ethical clearance for the experiment was sought from the University's Ethics Committee.

Table 2 Nutritional composition of coriander seed powder

\begin{tabular}{lc}
\hline Component & Amount (g/kg, dry matter basis ) \\
\hline Dry matter & 880 \\
Crude protein & 153 \\
Crude fibre & 336 \\
Ether extract & 200 \\
Ash & 95 \\
\hline
\end{tabular}

\section{Results and Discussion}

The effects of various dietary levels of coriander extract on the growth performance indices and carcass characteristics of Ross 308 broilers, aged 1 - 42 days, are presented in Table 3 . The results showed that coriander extract supplementation had no effect $(P>0.05)$ on the growth performance indices of chickens during the starter period. However, from $21 \mathrm{~d}$ to $42 \mathrm{~d}$ old, coriander extract in the drinking water improved the weight gain of broiler chickens (quadratic, $P<0.05$ ). Inclusion levels of $952 \mathrm{mg} / \mathrm{kg}$ of coriander extract in water optimized weight gain (Table 4). From $1 \mathrm{~d}$ to $42 \mathrm{~d}$ old, feed intake improved (linear, $P<0.05$ ) with the inclusion of $1000 \mathrm{mg} / \mathrm{kg}$ coriander extract in water, but no improvements were observed with further increases. Jang (2011) observed that feed intake and weight gain were improved significantly by the addition of coriander oil to the diet of broilers. According to Rahimi et al. (2011), the feed intake of broiler chickens was improved significantly by the addition of herbal extract at $42 \mathrm{~d}$ old. 
Table 3 Effect of coriander extract in drinking water on feed intake $(\mathrm{g} / \mathrm{bird} / \mathrm{d})$, weight gain $(\mathrm{g} / \mathrm{bird} / \mathrm{d})$, feed conversion rate and carcass characteristics of Ross 308 broilers aged 1 - $42 \mathrm{~d}$

\begin{tabular}{|c|c|c|c|c|c|c|c|}
\hline \multirow{2}{*}{ Measurements } & \multicolumn{4}{|c|}{ Coriander supplementation $(\mathrm{mg} / \mathrm{kg})$} & \multirow{2}{*}{ SEM } & \multicolumn{2}{|c|}{$P$-value } \\
\hline & 0 & 750 & 1000 & 1250 & & Linear & Quadratic \\
\hline \multicolumn{8}{|l|}{$1-21 d$} \\
\hline Feed intake & 49.9 & 49.1 & 52.2 & 51.2 & 25.1 & 0.36 & 0.69 \\
\hline Weight gain & 38.1 & 35.9 & 38.1 & 37.7 & 0.92 & 0.89 & 0.70 \\
\hline $\begin{array}{l}\text { Feed conversion } \\
\text { ratio }\end{array}$ & 1.31 & 1.37 & 1.37 & 1.36 & 0.02 & 0.12 & 0.06 \\
\hline \multicolumn{8}{|l|}{$21-42 d$} \\
\hline Feed intake & 155 & 152 & 163 & 160 & 78.1 & 0.43 & 0.78 \\
\hline Weight gain & 73.4 & 83.2 & 83.1 & 82.6 & 4.11 & 0.09 & 0.05 \\
\hline $\begin{array}{l}\text { Feed conversion } \\
\text { ratio }\end{array}$ & 2.11 & 1.83 & 1.98 & 1.94 & 0.10 & 0.37 & 0.50 \\
\hline \multicolumn{8}{|l|}{$1-42 d$} \\
\hline Feed intake & 102 & 101 & 108 & 106 & 89.6 & 0.05 & 0.10 \\
\hline Weight gain & 55.7 & 59.5 & 60.6 & 60.1 & 1.71 & 0.41 & 0.76 \\
\hline $\begin{array}{l}\text { Feed conversion } \\
\text { ratio }\end{array}$ & 1.84 & 1.69 & 1.79 & 1.76 & 0.03 & 0.49 & 0.60 \\
\hline \multicolumn{8}{|l|}{ Carcass characteristics } \\
\hline Live body weight $(\mathrm{kg})$ & 2.29 & 2.71 & 2.63 & 2.59 & 197 & 0.21 & 0.16 \\
\hline $\begin{array}{l}\text { Defeathered body weight } \\
(\mathrm{kg})\end{array}$ & 1.76 & 2.07 & 2.02 & 1.99 & 1.54 & 0.19 & 0.14 \\
\hline $\begin{array}{l}\text { Empty abdomen carcass } \\
\text { weight }(\mathrm{kg})\end{array}$ & 1.49 & 1.73 & 1.68 & 1.66 & 135 & 0.20 & 0.14 \\
\hline Eviscerated carcass (\%) & 76.9 & 76.3 & 76.5 & 76.9 & 0.75 & 0.91 & 0.04 \\
\hline Breast $\left(\mathrm{rel}^{1}\right) \%$ & 22.9 & 22.7 & 22.3 & 24.0 & 0.96 & 0.39 & 0.27 \\
\hline Drumsticks $\left(\mathrm{rel}^{1}\right) \%$ & 19.9 & 19.4 & 19.7 & 19.0 & 0.44 & 0.19 & 0.55 \\
\hline Wings $\left(\right.$ rel $\left.^{1}\right) \%$ & 5.49 & 5.98 & 6.19 & 5.84 & 0.44 & 0.26 & 0.36 \\
\hline Liver and bile $\left(\right.$ rel $\left.^{1}\right) \%$ & 0.54 & 0.55 & 0.52 & 0.54 & 0.05 & 0.75 & 0.96 \\
\hline Heart $\left(\mathrm{rel}^{1}\right) \%$ & 2.02 & 2.17 & 2.23 & 2.4 & 0.12 & 0.05 & 0.12 \\
\hline Gizzard $\left(\mathrm{rel}^{1}\right) \%$ & 2.48 & 2.15 & 2.07 & 2.4 & 0.22 & 0.55 & 0.36 \\
\hline Abdominal fat $\left(\mathrm{rel}^{1}\right) \%$ & 0.96 & 0.84 & 0.72 & 0.87 & 0.11 & 0.35 & 0.56 \\
\hline Intestine $\left(\mathrm{rel}^{1}\right) \%$ & 5.41 & 5.24 & 5.67 & 5.22 & 0.41 & 0.91 & 0.98 \\
\hline
\end{tabular}

${ }^{1}$ Weight of the organ relative to live weight.

Noticeable positive effects of essential oils on feed intake have also been documented (Hertrampt, 2001; Willams \& Losa, 2001). Phytogenic feed additives reportedly improve the flavour and palatability of feed, thus enhancing production performance (Windisch et al., 2008). Brenes \& Roura (2010) observed that herbs and spices and their active compounds act as food condiments through the oronasal (oral and nasal cavities) system. Oronasal sensing prepares the gastrointestinal tract for food reception and stimulates digestive secretions (Teff, 2000; Hiraoka et al., 2003). Furthermore, Jamroz et al. (2003) reported that herbs and spice extracts have appetite- and digestion-stimulating properties and antimicrobial effects. In contrast, other authors have reported non-significant effects of plant extracts on broiler feed intake and general bird performance (Boutsoglou et al., 2002; Lee et al., 2003a; b; Barreto et al., 2008). According to Lee et al. (2003a), the absence of effects on bird performance may be related to the composition of the basal diet and to the environmental conditions of the experiment. Feeds containing highly digestible ingredients limit the proliferation of bacteria in the intestinal tract because no substrate is left for bacterial growth, thereby reducing the antimicrobial potential of plant extracts (Lee et al., 2003a). This is also observed when birds are raised under low immune challenge conditions or strict health control. 
In this study, coriander extract in water did not improve FCR. This finding is similar to that of Hernández et al. (2004), who found no improvement in FCR of broilers supplemented with essential oil extract from oregano, cinnamon and pepper. It has been reported that environmental and genetic factors influence the chemical composition of plant essential oils and their extracts (Brenes \& Roura, 2010). Other factors that could affect the results of in vivo experiments are species and subspecies, geographical location, harvesting time and state of maturity of plants, parts of plant, extraction methods and duration of conservation of plant extracts (Cosentino et al., 1999; Juliano et al., 2000; Faleiro et al., 2002; Brenes \& Roura, 2010).

Most of the viscera and carcass variables were not affected by the level of coriander extract supplementation except for the eviscerated carcass and relative heart weight. Relative heart weight was augmented (linear, $P<0.05$ ) as coriander extract was increased in the water. Inclusion levels of $625 \mathrm{mg} / \mathrm{kg}$ and $101 \mathrm{mg} / \mathrm{kg}$ optimized these two parameters, respectively. Contrary to the present study, Aguilar et al. (2013) and Barcelos et al. (2010) reported a reduction in the relative weight of heart with increasing levels of supplementation of plant extract. The discrepancy in this result merits further study. Non-significant effects of plant extract on carcass yield have been reported by various authors (Hernández et al., 2004; Barreto et al., 2008; Aguilar et al., 2013).

The effects of dietary coriander powder supplementation levels on performance and carcass characteristics of Ross 308 broiler chickens aged 1 - $42 \mathrm{~d}$ are presented in Table 5. These growth production parameters were not influenced $(P>0.05)$ by supplementation during the starter period. However, during the grower stage and the entire experimental period, FCR improved (linear, $P<0.05$ ) with the supplementation level.

Table 4 Dietary coriander supplementation for optimal productivity and carcass characteristic of broiler chickens during the starter, grower and total periods

\begin{tabular}{|c|c|c|c|c|}
\hline Trait & Formula & $\begin{array}{c}r^{2} \\
\text { values }\end{array}$ & $\begin{array}{c}\text { Optimal } X \\
\text { value }\end{array}$ & Y-value \\
\hline \multicolumn{5}{|l|}{ Coriander extract } \\
\hline Weight gain ${ }^{1}(g / d)$ & $Y=73.4+0.021 X-0.00001103 X^{2}$ & 0.99 & 952 & 93.4 \\
\hline Eviscerated carcass $^{2}(\%)$ & $Y=76.9-0.002 X+0.0000016 X^{2}$ & 0.99 & 625 & 65.0 \\
\hline \multicolumn{5}{|l|}{ Coriander powder } \\
\hline Feed intake ${ }^{3}(\mathrm{~g} / \mathrm{d})$ & $Y=102+7.70 X-3.20 X^{2}$ & 0.98 & 1.2 & 107 \\
\hline
\end{tabular}

\footnotetext{
${ }^{1}$ Weight gain of broilers chickens during the growth period (21 - $\left.42 \mathrm{~d}\right)$.

${ }^{2}$ Carcass trait of broiler chickens at $42 \mathrm{~d}$ old.

${ }^{3}$ Feed intake of broiler chickens for the entire experimental period $(1-42 d)$.
}

Hamodi et al. (2010) and Al-Jaff (2011) reported similar results to those of the current study. The inclusion of coriander seed in the diets of broiler chickens resulted in improved FCRs. This improvement in feed conversion is owing to the active component (linalool) in coriander, causing greater efficiency in the utilization of feed, resulting in enhanced growth (Brenes \& Roura, 2010). Additionally, Przybilla \& Weiss (1998) reported that the mode of action of the herb mixtures on feed conversion takes place through the enhancement of digestive functions. Rajeshwari \& Andallu (2011) observed that coriander is an excellent appetizer and helps in the secretion of enzymes and digestive juices in the stomach, which stimulates digestion and peristaltic motion, thus improving FCR.

From $1 \mathrm{~d}$ to $42 \mathrm{~d}$ old, the feed intake of broiler chickens improved significantly (quadratic, $P<0.05$ ). Coriander powder supplementation of $1.2 \%$ optimized feed intake (Table 4). The improvement in the feed intake with the addition of coriander seed powder could be owing to essential oils and their main component, linalool, in coriander seeds. Çabuk et al. (2003) reported that linalool has an appetizing effect in diets and stimulates the digestive process in animals. Positive effects of essential oils on feed intake have also been reported previously (Ather, 2000; Hertrampf, 2001; Williams \& Losa, 2001). In the present trial, coriander powder supplementation level had no effect $(P>0.05)$ on the carcass traits. This result was in agreement with Case et al. (1995), Botsoglou et al. (2002), Jang et al. (2007) and Amouzmehr et al. (2012), who reported that the use of herbal plants had no effect on the dressing percentage of broiler chickens. 
Table 5 Effect of coriander powder on growth performance and carcass characteristics of Ross 308 broilers aged 1 - 42 days

\begin{tabular}{|c|c|c|c|c|c|c|c|}
\hline \multirow{2}{*}{ Measurements } & \multicolumn{4}{|c|}{ Coriander powder supplementation level (\%) } & \multirow{2}{*}{ SEM } & \multicolumn{2}{|c|}{$P$-value } \\
\hline & 0 & 1.5 & 2.0 & 2.5 & & Linear & Quadratic \\
\hline \multicolumn{8}{|l|}{$1-21 d$} \\
\hline Feed intake & 49.9 & 51.2 & 51.2 & 49.9 & 20.9 & 0.69 & 0.12 \\
\hline Weight gain & 38.1 & 40.0 & 38.8 & 39.0 & 1.11 & 0.49 & 0.54 \\
\hline $\begin{array}{l}\text { Feed conversion } \\
\text { ratio }\end{array}$ & 1.31 & 1.28 & 1.32 & 1.28 & 0.03 & 0.65 & 0.93 \\
\hline \multicolumn{8}{|l|}{$21-42 d$} \\
\hline Feed intake & 155 & 158 & 158 & 151 & 56.8 & 0.79 & 0.36 \\
\hline Weight gain & 73.3 & 84.1 & 84.7 & 81.8 & 3.99 & 0.17 & 0.06 \\
\hline $\begin{array}{l}\text { Feed conversion } \\
\text { ratio }\end{array}$ & 2.11 & 1.88 & 1.87 & 1.85 & 0.11 & 0.04 & 0.07 \\
\hline \multicolumn{8}{|l|}{$1-42 d$} \\
\hline Feed intake & 102 & 106 & 105 & 101 & 59.1 & 0.18 & 0.01 \\
\hline Weight gain & 55.7 & 62.0 & 61.7 & 60.4 & 1.37 & 0.88 & 0.32 \\
\hline $\begin{array}{l}\text { Feed conversion } \\
\text { ratio }\end{array}$ & 1.84 & 1.71 & 1.70 & 1.68 & 0.04 & 0.02 & 0.09 \\
\hline \multicolumn{8}{|l|}{ Carcass characteristics } \\
\hline Live body weight (kg) & 2.29 & 2.59 & 2.77 & 2.44 & 133 & 0.41 & 0.47 \\
\hline $\begin{array}{l}\text { De-feathered body } \\
\text { weight }(\mathrm{kg})\end{array}$ & 1.76 & 2.03 & 2.12 & 1.89 & 102 & 0.40 & 0.37 \\
\hline $\begin{array}{l}\text { Empty abdomen carcass } \\
\text { weight }(\mathrm{kg})\end{array}$ & 1.49 & 1.75 & 1.81 & 1.56 & 92.7 & 0.52 & 0.36 \\
\hline Eviscerated carcass (\%) & 76.9 & 78.1 & 76.5 & 77.5 & 0.80 & 0.76 & 0.92 \\
\hline Breast $\left(\mathrm{rel}^{1}\right) \%$ & 22.9 & 24.7 & 23.5 & 25.6 & 1.16 & 0.23 & 0.63 \\
\hline Drumsticks $\left(\mathrm{rel}^{1}\right) \%$ & 19.9 & 19.7 & 18.4 & 18.6 & 0.44 & 0.16 & 0.49 \\
\hline Wings $\left(\mathrm{rel}^{1}\right) \%$ & 5.49 & 6.15 & 5.87 & 6.97 & 0.53 & 0.17 & 0.47 \\
\hline Liver and bile $\left(\right.$ rel $\left.^{1}\right) \%$ & 0.54 & 0.48 & 0.45 & 0.55 & 0.15 & 0.77 & 0.51 \\
\hline Heart $\left(\right.$ rel $\left.^{1}\right) \%$ & 2.02 & 1.98 & 2.21 & 2.17 & 0.05 & 0.32 & 0.63 \\
\hline Gizzard $\left(\mathrm{rel}^{1}\right) \%$ & 2.48 & 2.17 & 2.6 & 2.47 & 0.18 & 0.91 & 0.82 \\
\hline Abdominal fat $\left(\mathrm{rel}^{1}\right) \%$ & 0.96 & 0.74 & 0.63 & 1.02 & 0.13 & 0.82 & 0.51 \\
\hline Intestine $\left(\right.$ rel $\left.^{1}\right) \%$ & 5.41 & 4.83 & 5.71 & 6.57 & 0.39 & 0.44 & 0.14 \\
\hline
\end{tabular}

${ }^{1}$ Weight of visceral organ relative to live weight.

\section{Conclusions}

In the current study, coriander supplementation generally improved production performance of broiler chickens. A coriander powder supplementation level of 1.2\% maximized feed intake of broiler chickens, while weight gain was maximized at an inclusion level of $952 \mathrm{mg} / \mathrm{kg}$ of coriander extract in drinking water. Increases in coriander seed powder supplementation resulted in improved FCRs. Coriander may therefore present an opportunity to enhance broiler performance when used as a dietary supplement. However, further research is required to establish the mode of action of the bioactive compounds in this herb.

\section{Acknowledgements}

Financial support by Islamic Azad University, Rasht Branch, Iran, grant no 4.5830 for is acknowledged.

\section{References}

Aguilar, C.A.L., Lima, K.R., Manno, M.C., Fernando, B.T., Vanessa, P. \& Neto, D.L.F., 2013. Effect of copaiba essential oil on broiler chickens' performance. Acta Sci. 32, 145-152. 
Al-Jaff, F.K., 2011. Effect of coriander seeds as diet ingredient on blood parameters of broiler chicks raised under high ambient temperature. Int. J. Poult. Sci. 2, 82-86.

Amouzmehr, A., Dastar, B., Ghassemi, J., Sung, K., Lohakare, J. \& Forghani, F., 2012. Effects of garlic and thyme extracts on growth performance and carcass characteristics of broiler chicks. J. Anim. Sci. Technol. 54, 185-190.

AOAC, 1990. Official Methods of Analysis (15th ed.). Association of Official Analytical Chemists, Inc., Washington D.C., USA.

Ather, M.A.M., 2000. Polyherbal additive proves effective against vertical transmission of IBD. World Poultry 16, 50-52.

Barcelos, F.F., Oliveira, M.L., Giovaninni, N.P.B., Lins, T.P., Filomeno, C.A., Schneider, S.Z., Pinto, V.D., Endringer, D.C. \& Andrade, T.U., 2010. Phytochemistry and cardiovascular biological activity of the essential oil of leaves Alpinia zerumbet in rats. Rev. Bras. Med. Plants 12, 48-56.

Barreto, M.S.R., Menten, J.F.M., Racanicci, A.M.C. \& Rizzo, P.V., 2008. Plant extracts used as growth promoters in broilers. Braz. J. Poult. Sci. 10, 109-115.

Botsoglou, N.A., Florou-Paner, P., Christaki, E., Fletouris, D.J. \& Spais, A.B., 2002. Effect of dietary oregano essential oil on performance of chickens and on iron-induced lipid oxidation of breast, thigh and abdominal fat tissues. Br. Poult. Sci. 43, 223-230.

Brenes, A. \& Roura, E., 2010. Essential oils in poultry nutrition: Main effects and modes of action. Anim. Feed. Sci. Technol. 15, 1-14.

Çabuk, M., Alçiçek, A., Bozkurt, M. \& İmre, N., 2003. Antimicrobial properties of the essential oils isolated from aromatic plants and using possibility as alternative feed additives. II. National Animal Nutrition Congress. 18-20 September, Konya, Turkey. pp. 184-187.

Case, G.L., He, L., Mo, H. \& Elson, C.E., 1995. Induction of geranyl pyrophosphate pyrophosphatase activity by cholesterol-suppressive isoprenoids. Lipids 30, 223-230.

Cosentino, S., Tuberoso, C.I.G., Pisano, B., Satta, M., Mascia, V., Arzedi, E. \& Palmas, F., 1999. In vitro antimicrobial activity and chemical composition of Sardinian thymus essential oils. Lett. Appl. Microbiol. 29, 130-135.

Faleiro, M.L., Miguel, M.G., Ladeiro, F., Venancio, F., Tavares, R., Brito, J.C., Figueiredo, A.C., Barroso, J.G. \& Pedro, L.G., 2002. Antimicrobial activity of essential oils isolated from Portuguese endemic species of Thymus. Lett. Appl. Microbiol. 36, 35-40.

Gray, A.M. \& Flatt, P.R., 1999. Insulin-releasing and insulin-like activity of the traditional anti-diabetic plant Coriandrum sativum (coriander). Br. J. Nutr. 81, 203-209.

Güler, T., Ertaş, O.N., Çiftçi, M. \& Dalkılıç, B., 2005. The effect of coriander seed (Coriandrum sativum L) as diet ingredient on the performance of Japanese quail. S. Afr. J. Anim. Sci. 35, 260-266.

Hamodi, S.J., Al-Mashhadani, E.H., Al-Jaff, F.K. \& Al-Mashhadani, H.E., 2010. Effect of coriander seed (Coriandrum sativum L.) as diet ingredient on broilers performance under high ambient temperature. Int. J. Poult. Sci. 9, 968-971.

Hernández, F., Madrid, J., Garcia, V., Orengo, J. \& Megias, M.D., 2004. Influence of two plant extracts on broilers performance, digestibility and organ size. Poult. Sci. 83, 169-174.

Hertrampt, J.W., 2001. Alternative antibacterial performance promoters. Poult. Int. 40, 50-52.

Hiraoka, T., Fukuwatari, T., Imaizumi, M. \& Fushiki, T., 2003. Effects of oral stimulation with fats on the cephalic phase of pancreatic enzyme secretion in esophagostomized rats. J. Physiol. Behav. 79, 713-717.

Jamroz, D., Werlecki, T.J., Wiliczkiewicz, A. \& Skorupinska, J., 2003. Influence of photogenic extracts on gut microbial status in chickens. In: Proceeding of the 14th European Symposium on Poultry Nutrition, August, Lillehammer, Norway. p. 176.

Jang, J.P., 2011. Effect of different levels of coriander oil on performance and blood parameters of broiler chickens. Ann. Biol. Res. 2, 578-583.

Jang, I.S., Ko, Y.H., Kang, S.Y. \& Lee, C.Y., 2007. Effect of commercial essential oil on growth performance, digestive enzyme activity and intestinal microflora population in broiler chickens. Anim. Feed Sci. Technol. 134, 304-315.

Jiménez-Moreno, E., Chamorro, S., Frikha, M., Safaa, H.M., Lazaro, R. \& Mateos, C.G., 2011. Effects of increasing levels of pea hulls in the diet on productive performance and digestive traits of broilers from one to eighteen days of age. Anim. Feed Sci. Technol. 168, 100-112.

Juliano, C., Mattana, A. \& Usai, M., 2000. Composition and in vitro antimicrobial activity of the essential oil of Thymus herba-barona Loisel growing wild in Sardinia. J. Essential Oil Res. 12, 516-522.

Lee, K.W., Everts, H., Kappert, H.J., Frehner, M., Losa, R. \& Benyen, A.C., 2003a. Effects of dietary essential oil components on growth performance, digestive enzymes and lipid metabolism in female broiler chickens. Br. Poult. Sci. 44, 450-457. 
Lee, K.W., Everts, H., Kappert, H.J., Yeom, K.H. \& Beynen, A.C., 2003b. Dietary carvacrol lowers body weight but improves feed conversion in female broiler chickens. J. Appl. Poult. Res. 12, 394-399.

Lippens, M., Huyghebaert, G. \& Cerchiari, E., 2005. Effect of the use of coated plant extracts and organic acids as alternatives for antimicrobial growth promoters on the performance of broiler chickens. Eur. Poult. Sci. 6, 48-56.

Madsen, H.L. \& Bertelsen, G., 1995. Spices as antioxidant. Trends Food Sci. Technol. 6, 271-277.

McDonald, P., Edwards, R.A., Greenhalgh, J.F.D., Morgan, C.A., Sinclair, L.A. \& Wilkinson, R.G., 2001. Animal Nutrition. Seventh ed., Prentice Hall, London.

Nadeem, M., Anjum, F.M., Khan, M.I. \& Tehseen, S., 2013. Nutritional and medicinal aspects of coriander (Coriandrum sativum L.). A review. Br. Food J. 115, 743-755.

NRC, 1994. Nutrient Requirements of Poultry. (9th rev. ed.). National Research Council, National Academy Press, Washington, D.C., USA.

Pathak, N.L., Kasture, S.B., Bhatt, N.M. \& Rathod, J.D., 2011. Phytopharmacological properties of Coriandrum sativum as a potential medicinal tree: an overview. J. Appl. Pharm. Sci. 1, 20-25.

Przybilla, P. \& Weiss, J., 1998. Herbal feed additives in pigs. DGS-Magazine 40, 52-57.

Rahimi, S., Zadeh, Z.T., Torshizi, M.A.K., Omidbaigi, R. \& Rokni, H., 2011. Effect of the three herbal extracts on growth performance, immune system, blood factors and intestinal selected bacterial population in broiler chickens. J. Agric. Sci. Technol. 13, 527-539.

Rajeshwari, U. \& Andallu, B., 2011. Medicinal benefits of coriander (Coriandrum sativum L). Spatula DD, 1, 51-58.

SAS, 2008. Statistical Analysis System. SAS User Guide: Release 9.2. SAS Institute INC, Cary N.C., USA.

Sasaki, Y.F., Kawaguchi, S., Kamaya, A., Ohshita, M., Kabasawa, K., Iwama, K., Taniguchi, K. \& Tsuda, S., 2002. The comet assay with 8 mouse organs: Results with 39 currently used food additives. Mutation Research/Genet. Toxicol. Environ. Mutagenesis 519, 103-119.

Teff, K., 2000. Nutritional implications of the cephalic-phase reflexes: Endocrine responses. Appetite J. 34, 206-213.

Wenk, C., 2006. Are herbs, botanicals and other related substances adequate replacements for antimicrobial growth promoters? In: Antimicrobial Growth Promoters. Eds: Barug, D., de Jong, J., Kies, A.K. \& Verstegen, M.W.A., Wageningen Academic Publishers, The Netherlands. pp. 329-340.

Williams, P. \& Losa, R., 2001. The use of essential oils and their compounds in poultry nutrition. World Poultry-Elsevier, 17, 14-15.

Windisch, W., Schedle, K., Plitzner, C. \& Kroismayr, A., 2008. Use of phytogenic products as feed additives for swine and poultry. J. Anim. Sci. 86, (E. Suppl.), E140-E148. 